
лікування, раціонально фармакотерапі, диспансеризаці та реабілітаці в практиці сімейного лікаря»

УДК 616.-08:61.254.1

\title{
СУЧАСНІ АСПЕКТИ ЗАСТОСУВАННЯ ДІУРЕТИКІВ В ПРАКТИЦІ КАРДІОЛОГА
}

\section{๑О. В. Давидович, Н. Я. Давидович, В. О. Лихацька, Т. Р. Волощук}

Національна медична академія післядипломної освіти імені П. Л. Шупика

\author{
ДВНЗ «Тернопільський державний медичний університетімені І. Я. Горбачевського МОЗ України»
}

РЕЗЮМЕ. У випадках високого функціонального класу серцево недостатності необхідно призначати кілька діуретиків, а ефективність торасеміду у хворих зі зниженою ФВ лівого шлуночка були більша, ніж при застосуванні інших діуретиків.

КЛЮЧОВІ СЛОВА: діуретики, ХСН, артеріальна гіпертензія.

Вступ. Відомо, що одним із механізмів підвищення артеріального тиску є затримка іонів $\mathrm{Na}+$ та води, що викликає зростання об'єму циркулюючо крові (ОЦК) та гіперкаліємію. Діуретики, збільшуючи експресію натрію з сечею, зменшують об' $є$ м плазми та позаклітинно рідини, знижують фракцію викиду (ФВ) лівого шлуночка, зменшують артеріальний тиск (АТ).

Основна частина. В даний час показання до призначення діуретиків можна поділити на три категорі : перша - хворі з серцевою недостатністю (з метою виведення надлишку рідини з організму), друга - пацієнти з артеріальною гіпертензією (АГ), третя - Хворі з IXC, у яких, з великою імовірністю, найближчим часом можуть розвинутись ознаки $\mathrm{XCH}$.

Відомо, що межа діуретично терапі - зменшення задишки, запобігання розвитку набряків, зменшення х вираженості, розвантаження серця. При проведенні терапі діуретиками слід пам'ятати про можливість активаці нейрогуморальних систем та розвитку водно-електролітного дисбалансу. Таким чином, чим більший діурез, тим сильніша реабсорбція води та іонів натрію, тим вираженіші диселектролітні порушення та гіперренінемія. Тому призначати діуретики слід не ударними дозами кілька разів на тиждень, а середніми і щоденно. Для компенсаці можливо гіперактиваці нейрогуморальних систем слід призначати інгібітори АПФ або антагоністи альдостерону.

Алгоритм призначення сечогінних препаратів при серцевій недостатності наступний:

- при XСН I ФК діуретики не призначають;
- при ХСH II ФК (компенсована СН) рекомендовано призначати діуретик;

- при XCH III ФК (декомпенсована СН) показане призначення двох діуретиків, як правило, тіазидного та антагоніста мінералокортико дних рецепторів для запобігання втраті калію;

- при XCH IV ФК до сечогінно терапі додають методи механічно евакуаці рідини з плеврально та черевно порожнин.

Окремо слід зупинитись на більш сучасному сечогінному препараті - торасеміді. Клінічною перевагою торасеміду $є$ його здатність незалежно від ФВ лівого шлуночка зменшувати розміри серця, локально блокувати симпато-адреналову та ренінальдостеронову системи, що забезпечує додатковий захист серця. Адже відомо, що власне ангіотензин II та альдостерон, сумісно діючи на фібробласти, стимулюють утворення нерозчинного колагену, що в кінцевому результаті викликає розвиток фіброзу міокарда при АГ та ХCH. Bce це погіршує роботу серця, так як фіброз міокарда збільшує жорсткість та зменшує еластичність міокарда, викликаючи таким чином прогресування діастолічно дисфункці . Метаболічна нейтральність торасеміду дозволяє призначати його пацієнтам з метаболічними порушеннями, зокрема при цукровому діабеті, в середньодобовій дозі 14,5 мг на добу.

Висновок. Терапевтичний ефект торасеміду у хворих зі зниженою ФВ лівого шлуночка вищий, ніж при призначенні інших діуретиків. У випадках наявності високого ФК ХCH пацієнтам необхідно призначати потужну комбіновану діуретичну терапію. 